\title{
LOOK FOR HIM UNDER YOUR BOOTSOLES... OR IN HIS PROSE ${ }^{2}$
}

\begin{abstract}
the paper focuses on Walt Whitman's collection of autobiographic essays Specimen Days in relation to his poetry. Comparing and contrasting specific poems and essays we can note significant similarities in terms of style and themes. Whitman's prose displays recognizable stylistic features characteristic of his poetry, such as repetition, parallelism, and cataloguing. When it comes to themes, particularly interesting is the comparison of Whitman's prose and poetic representations of the Civil War. Apart from this, Specimen Days offers an invaluable insight into Whitman's poetic principles, through the discussion of the structure and organization of the book. On the basis of this analysis we come to the conclusion that Whitman's prose is not only valuable in itself, but should be considered an important complementary material for studying his poetry.

Keywords: autobiography, metapoetics, American poetry, Walt Whitman, Specimen Days
\end{abstract}

\section{Introduction}

When Walt Whitman's “curious" collection of 12 long poems, entitled Leaves of Grass, first appeared in 1855, it met with several rather skeptical reviews, one of which remarked the book contained "lines of rhythmical prose" ([Anonymous] 1855), while another noted that the presented poems were "neither in rhyme nor blank verse, but in a sort of excited prose broken into lines without any attempt at measure or regularity" (Norton 1855). This early impression that Whitman's poetry is some kind of "excited prose" becomes even more compelling upon comparing his poems to his prose writings, which reveals certain idiosyncrasies occurring in both. It is quite conspicuous that Whitman's poetry refuses to fit into any conventional genre category - it is neither epic, nor lyric, in the traditional senses of the terms, and although the literary public has long acknowledged that it is poetry, the irregularity of unrhymed free verse, the narrative passages ${ }^{3}$ and the specific stylistic features, like catalogues, suggest a close connection to prose writing.

1 bojana.acamovic@gmail.com

2 The paper was presented at the $7^{\text {th }}$ Annual Walt Whitman Symposium: Whitman Across Genres, held at the University of Bamberg (Germany), July 25-26, 2014. The paper is part of the research conducted on the project Serbian Literature in the European Cultural Space (178008) funded by the Serbian Ministry of Education, Science, and Technological Development.

3 Examples of such passages in "Song of Myself" would be the encounter with the runaway slave (Section 10) and the account of the battle of the Alamo (Section 34). 
While discerning a number of prose-like features in Whitman's poetry, we can also trace Whitman's poetic practices at work in his prose pieces, which therefore can be regarded as complementary to his poems. The 1855 edition of Leaves of Grass begins with the prose "Preface", introducing the reader to the new poetry and defining the American poet. These metapoetic observations on poetry-writing are further developed in Whitman's later prose works (in Prefaces to later editions of poetry and in Democratic Vistas) and are also encountered in his autobiographic work, Specimen Days. First published in 1882 as part of the volume Specimen Days \& Collect, this collection of essays contains pieces referring to (and written at) various points of the poet's life and can be divided into four parts: a concise record of his family history and his youth, a more extensive account of the Civil War (mainly reprinted from the previously published Memoranda During the War), the poet's thoughts on nature and natural phenomena, and a series of essays on notable personalities and various social issues. Betsy Erkkila observes the book's likeness to Leaves of Grass in terms of its themes, but also in terms of the narrating voice: "Like Whitman's poetic persona, the narrator of Specimen Days shuttles back and forth between self and aggregate, nature and city, solitude and society, matter and spirit. There is a similar dualism or balance of voices" (Erkkila 1996: 295). Apart from this, the very structure of Specimen Days reflects the organizational principle Whitman applied in his poetry collections. This assortment of diverse essays of different length corresponds to the patchwork structure of "Song of Myself" and the whole volume serves as a prose counterpart of Leaves of Grass. As Ed Folsom notes, Leaves and Specimen Days \& Collect were even published in a matching binding "so that buyers could own an attractive set of Whitman's work" (Folsom 2005: 54).

Specimen Days contains observations on poetry, literature, writing and writers, as well as discussions of Whitman's own poetry and writing practices, and these auto-referential passages provide a valuable insight into his work. Apart from this meta-level of writing about writing, Specimen Days displays the interrelation of poetry and prose on the level of themes and styles. Therefore, in addition to discussing meta-/autopoetic references, this paper will also consider the thematic and stylistic parallels in Whitman's poetry and prose, in an attempt to demonstrate a close relation between the two modes of writing in the work of a single poet.

\section{Whitman's themes and style - poetry vs. prose}

The thematic and stylistic parallels which make Whitman's poems and prose texts so closely related can be observed as early as the first edition of Leaves. A brief look at the 10-page "Preface" reveals features that will appear in the poems as well - idiosyncratic punctuation with ellipses and hyphens, as well as the characteristic Whitmanesque catalogues. Discussing the style

4 The 1855 „Preface“ itself is an example of close relation between Whitman's poetry and prose - it reappeared arranged in verses and incorporated in the poem „By Blue Ontario's Shore." 
of Whitman's poetry, James Perrin Warren concludes that "the distinction between prose and poetry is questionable," also noting that "the 1855 Preface is marked by repetition, syntactic parallelism, cataloguing, and direct address, the very techniques that Whitman uses in the poems of 1855 and 1856" (Warren 2006: 382). An illustration of this appears almost at the beginning of "Preface," in a catalogue describing the American people:

Their manners speech dress friendships - the freshness and candor of their physiognomy - the picturesque looseness of their carriage ... their deathless attachment to freedom - their aversion to anything indecorous or soft or mean - the practical acknowledgment of the citizens of one state by the citizens of all other states [...] these too are unrhymed poetry (Whitman 1996: 6).

Whitman's inclination towards cataloguing, often explained by his work of a journalist, is revealed in his late prose pieces, as well. The long lists from his notebooks, which found their way into his poems, are revoked in such Specimen Days essays as "Birds and Birds and Birds," "Wild Flowers," and "A Civility Too Long Neglected," in which the lists of different species of plants and animals resemble a draft for a poem. In the essay on Delaware River, Whitman turns to a long catalogue to describe the surroundings: "But let me bunch and catalogue the affair - the river itself, all the way from the sea - Cape Island on one side and Henlopen light on the other [...]" (Whitman 1996: 856). A possible explanation for such fondness of cataloguing could be Whitman's belief that the poet should not be too specific or scientific about the phenomena he describes, as expressed in his essay "Birds - and a Caution": "[A] certain free margin, and even vagueness - perhaps ignorance, credulity - helps your enjoyment of these things, and of the sentiment of feather'd, wooded, river, or marine Nature generally" (Whitman 1996: 929). Catalogues enabled Whitman to encompass and juxtapose a great number of things without tiring his readers with too elaborate explanations and this made them a useful poetic tool both in his poetry and his prose.

Being a prose counterpart of Leaves of Grass, with essays written at different points of the author's life, Specimen Days quite naturally presents similar themes. Whitman's fascination with the sky and the celestial objects, for instance, emerges in his prose as well and these features are evoked with a similar aim - to create an atmosphere of calmness and peace as opposed to the burdening reality of everyday life. The poem "When I Heard the Learn'd Astronomer" and the essay "A Silent Night Ramble" both present an image of the poet oppressed by scientific lecturing and hospital scenes respectively, and seeking comfort in nightly wanderings under the firmament of magnificent planets and constellations.

The same themes are, however, sometimes presented differently as they are approached from different angles. The author focuses on different aspects of a given event or attempts to provoke different sentiments. The "Drum-Taps" poem "Bivouac on a Mountain Side" and the essay "A Cavalry Camp" depict essentially the same event, i.e. an army unit putting up a camp for the night. In the two pieces Whitman's style is descriptive and the short sentences of the es- 
say almost could be "converted" into lines of a free-verse poem, which would approximately look like this:

There are the men in their yellow-striped jackets.

All are dismounted;

The freed horses stand with drooping heads and wet sides;

they are to be led off presently in groups, to water.

The little wall-tents and shelter tents spring up quickly.

I see the fires already blazing, and pots and kettles over them. ${ }^{5}$

However, the poet's vision in the prose piece is different from the one in the poem - the poem is mainly focused on the natural surroundings, only briefly noting "the shadowy forms of men and horses," and ending with the sky - "the sky! far, far out of reach, studded, breaking out, the eternal stars." (Whitman 1996: 435) The essay, on the other hand, offers no such cosmic flights, is rather matter-of-fact, and focuses on describing the soldiers and their activities in the camp. The scene depicted in the poem is quite static; in the essay, it is more dynamic. The verses emphasize the grandeur of nature, larger than war, whereas the prose piece, in a journalistic manner, aims to capture "a hundred little things going on." In this manner the prose complements the poetry, and it thus seems appropriate or even necessary to read "Drum Taps" along with the poet's "Civil War" notes.

Different approaches to the same theme tend to render a different tone in a poem or an essay, which is demonstrated by Whitman's poetry and prose written on occasion of Abraham Lincoln's death. Honoring the assassinated President, Whitman wrote four poems (later included in "Memories of President Lincoln", in Leaves of Grass) ${ }^{6}$ and a note, "Murder of President Lincoln," published in Memoranda During the War. The greater part of this note subsequently became part of a lecture entitled "Death of Abraham Lincoln," first delivered on April 14, 1879. The final, bracketed paragraph of Whitman's note was republished as a short essay in Specimen Days, under the title "Death of President Lincoln." This essay glorifies Lincoln as "the greatest, best, most characteristic, artistic, moral personality" (Whitman 1996: 787) and, interestingly, conveys the tone that is considerably different from the corresponding poems. The prevailing mourning and meditative sentiments of "When Lilacs Last in the Dooryard Bloom'd" and "Oh Captain! My Captain!" are countered by the optimistic and victorious ending of the Specimen Days essay: "He was assassinated - but the Union is not assassinated - ça ira! [...] Death does its work, obliterates a hundred, a thousand - President, general, captain, private - but the Nation is immortal!" (Whitman 1996: 788) Whitman's Specimen Days piece praises the American nation even more than its assassinated President and replaces a factual report of the assassination, so carefully laid out in the lecture, with the emphasis on the nation's immortality.

5 See the original prose text in Whitman 1996: 753-4.

6 These are: "When Lilacs Last in the Dooryard Bloom'd," "Oh Captain! My Captain!," "Hush'd Be the Camps Today," and "This Dust was Once the Man." 
Therefore, the effect of the Specimen Days essay is undeniably more in line with Whitman's ideas on death presented in "Song of Myself."

\section{Towards a new poetry - metapoetic and autopoetic observations}

Walt Whitman has long played the role of the American national poet and the father of the distinctly American poetry, which is the role he created for himself, not solely through his verses, but equally (and more explicitly) through his prose. Starting from the 1855 "Preface" and up to the essays in Specimen Days, in his metapoetic passages Whitman elaborates on his ideas of American poetry and American poet, also pointing to the most suitable themes this poet should explore. The Specimen Days essays further expound on this subject, but also present auto-referential remarks, through which the author discusses his own poetry and provides an insight into some of his writing choices and poetic principles. In addition, Whitman occasionally reviews his writing of Specimen Days, offering metanarrative comments which sometimes resemble those found in works of postmodernist authors.

Trying to outline a new course of American poetry, Whitman frequently stresses the necessity of it becoming independent from any European, and particularly British influence. In the essay "Mississippi Valley Literature" the poet remarks:

One's mind needs but a moment's deliberation anywhere in the United States to see clearly enough that all the prevalent book and library poets, either as imported from Great Britain, or follow'd and doppelgang'd here, are foreign to our States, copiously as they are read by us all (Whitman 1996: 890).

Persistently voicing his belief that American poets should make a culture-specific poetry rooted in the American soil, and not act as European epigones, the poet further wonders: "Will the day ever come [...] when those models and lay-figures from the British islands - and even the precious traditions of the classics - will be reminiscences, studies only?" (Whitman 1996: 890) To achieve this, Whitman advises turning to characteristically American themes, such as the vast American regions, East and West, and these potential poetic themes are common subjects of his Specimen Days essays. Reflecting on the East, the poet exclaims: "What a subject for a poem! Indeed, where else a more pregnant, more splendid one?" (Whitman 1996: 850) Further on, the account of his Western journey is punctuated with his insistence on adopting the American landscape as the subject of poetry and art: "Yes, I think the chyle of not only poetry and painting, but oratory, and even the metaphysics and music fit for the New World, before being finally assimilated, need first and feeding visits here." (Whitman 1996: 882) In the essay celebrating the natural beauty of Illinois, Missouri, Kansas and Colorado ("The Prairies and Great Plains in Poetry") the poet suggests that "it would be grander still to see

7 As regards death, Whitman advocated a fairly optimistic view according to which death is merely a phase in a person's life, leading to the creation of another life, and should not be feared of. 
all those inimitable American areas fused in the alembic of a perfect poem, or other esthetic work, entirely western, fresh and limitless - altogether our own, without a trace or taste of Europe's soil, reminiscence, technical letter or spirit" (Whitman 1996: 887), which echoes Whitman's claim from the 1855 "Preface" that "the United States themselves are essentially the greatest poem." (Whitman 1996: 5) As seen from these passages, although Whitman's poetic production considerably slackened towards the end of his life, his exhilaration over the American regions as subjects for poems had not diminished. He continues to point to potential poetic themes but the accomplishment of this task is left to future poets.

On the one hand, both in his poems and his prose, Whitman puts forward his unconventional ideas on poetry-writing, with the intention of inspiring future poets to embrace and implement them. Some of his principles are today recognized as proto-versions of modern literary theories and poetic techniques. ${ }^{8}$ On the other hand, Whitman expressed aversion to any theory that would serve as an authoritative guide for writing, reading and interpreting poetry. His attitude towards theoretical approaches to literature is explicitly voiced in the essay "After Trying a Certain Book." The book in question was "a beautifully printed and scholarly volume on 'the Theory of Poetry,"' sent to him from England, which he "gave [...] up at last for a bad job" (Whitman 1996: 947). Whitman here voices his discontent with some critics' explanations of poems and their meanings and he counters the common question "What does it mean?" with his own - "Symphony of fine musician, or sunset, or sea-waves rolling up the beach - what do they mean?" (Whitman 1996: 947) ${ }^{9}$ Whitman's relation to poetry is sooner mystical than intellectual and the poet persistently shuns theoretical explanations believing that they reduce the joy provided by the elusiveness of meaning. Perhaps paradoxically, precisely in this essay, i.e. in Whitman's statement that "[t]he play of Imagination, with the sensuous objects of Nature for symbols, [...] make up the curious chess-game of poem" (Whitman 1996: 947), Roger Asselineau recognizes "the fundamental principles of symbolism," observing that although these ideas had already been introduced in the theories of romantics and transcendentalists, "no one had yet applied them with as much audacity as Whitman" (Asselineau 1999: 211).

In his autobiographic notes, Whitman occasionally refers to his own poems and offers additional clarifications. In the essay "Paumanok, and My Life on It As Child and Young Man," amid the description of Long Island, Whitman mentions frequent shipwrecks and particularly the loss of the ship "Mexico" in 1840, adding that the incident was "alluded to in 'the Sleepers' in L. of G." (Whitman 1996: 720). In this manner, he informs the reader of a specific event serving as an inspiration for a poem, which otherwise could

8 Among Whitman's contributions is his rejection of strict rules of versification, eventually leading to the concept of free verse, as well as his demand for an active reader, now at the base of the Reader-Response criticism.

9 Stylistically this again evokes a passage in "Song of Myself": "Do you take it I would astonish? / Does the daylight astonish? or the early redstart twittering through the woods? / Do I astonish more than they?" (Whitman 1996: 45) 
not be inferred from the poem itself. More importantly, Whitman points to certain fundamental principles of his poetry-writing. In "My Passion for Ferries," whose very title evokes the poem "Crossing Brooklyn Ferry," Whitman intimates: "Indeed, I have always had a passion for ferries; to me they afford inimitable, streaming, never-failing, living poems" (Whitman 1996: 725). This observation goes beyond the thematic level and uncovers the principles of his art. The scenery which Whitman took in on his ferry-rides provided the images for his poems, but it also affected their structure. In the case of "Crossing Brooklyn Ferry" James Dougherty observed that "in its themes and form [the poem] is circular and repetitive, a ferry-like shuttling between alternatives" (Dougherty 2006: 485, my emphasis). Moreover, the basic idea of ferries as vessels transporting millions of people in the past, present and future entered the core of Whitman's poetry, which has become a means of sharing experiences with future generations.

A similar autopoetic insight into Whitman's poetry is found in the essay "Sea-Shore Fancies": "Even as a boy, I had the fancy, the wish, to write a piece, perhaps a poem, about the sea-shore" (Whitman 1996: 820). Whitman's fascination with the sea produced some of the most memorable poetic images, for example in the poem "As I Ebb'd with the Ocean of Life." However, apart from this thematic connection, in the same essay Whitman again explicitly points to some of his poetic principles: "Afterward, I recollect, how it came to me that instead of any special lyrical or epical or literary attempt, the seashore should be an invisible influence, a pervading gauge and tally for me, in my composition" (Whitman 1996: 820, my emphasis). As in the case of ferries, the sea-shore is not only the source of powerful imagery, but also the source of ideas that surpass one particular poem and pervade his whole oeuvre. ${ }^{10}$

The fact that metapoetic observations in Specimen Days appear more frequently in his Nature-notes confirms Whitman's fundamental idea of poetry-writing being similar to phenomena occurring in nature. ${ }^{11}$ Explicit pointing to nature as a source of his poetry is encountered in "An Egotistical 'Find," where the poet relates: "'I have found the law of my own poems,' was the unspoken but more-and-more decided feeling that came to me as I pass'd, hour after hour, amid all this grim yet joyous elemental abandon" (Whitman 1996: 879). By describing the "untrammel'd play of primitive Nature" using

10 This note could be considered as more than an autopoetic observation or an attempt at "explaining" his poetry to the reader. In the following sentence (given in brackets, as an aside), Whitman offers "a hint here to young writers," (Whitman 1996: 820) therefore continuing his mission of the poet-instructor, started with the 1855 "Preface" and aimed at the poets to come.

11 Considering Specimen Days as a whole, we may notice that the Civil-War part is mostly narrative, whereas the Nature-notes are more given to metanarrative or metapoetic observations. This is in accordance with the organic principles of Whitman's poetry and the omnipresent parallels between nature and literature. In his first "Nature-note" the poet remarks that "the pages now ensuing may carry ray of sun, or smell of grass or corn, or call of bird, or gleam of stars by night, or snow-flakes falling fresh and mystic [...]" (Whitman 1996: 804, footnote) and that his notes "may seem hardly more than breaths of common air, or draughts of water to drink” (805). 
his characteristic cataloguing, Whitman reveals the underlying principle of his poetry - his poetry is to follow the laws of nature and not of art, i.e. to be natural and not artificial.

As seen from his metapoetic observations, Whitman had quite definite notions regarding the practice of poetry-writing and his auto-referential notes prove how meticulously and carefully he approached composing his verses. However, can the same be said in relation to his prose? Apart from discussing poetry, in Specimen Days Whitman occasionally pauses to consider his current prose composition. In doing so, he usually lacks the self-assuredness he demonstrates in his poetry.

Whitman's collection of autobiographic essays, notes and sketches starts in a manner somewhat resembling metanarrative passages of postmodernist fiction: "If I do it at all I must delay no longer." (Whitman 1996: 713) This peculiar "anxiety of beginning" foreshadows further expressions of author's hesitancy and insecurity encountered in several other places in Specimen Days. Although the essay is entitled "A Happy Hour's Command," it appears that for Whitman the actual hour of writing is by no means a happy one. Insecure about presenting his "huddle of diary-jottings, war-memoranda of 1862-'65, Nature-notes of 1877-'81, with Western and Canadian observations afterwards," Whitman is loafing and making wayward digressions - "the resolution and indeed mandate comes to me this day, this hour, - (and what a day! what an hour just passing! the luxury of riant grass and blowing breeze, with all the shows of sun and sky and perfect temperature, never before so filling me body and soul)" (Whitman 1996: 713). The footnote accompanying this essay provides information about the specific time and circumstances in which particular groups of essays were composed, giving some critics the basis to conclude that Specimen Days starts "in the typical Whitman fashion, with the author full of confidence" (Balkun 1999: 17). This conclusion, however, could be reconsidered having in mind that even in the said footnote the author stumbles a little when explaining his reasons for writing and eventually admits that "the book is probably without any definite purpose that can be told in a statement" (Whitman 1996: 714, my emphasis).

The uncertainty about the form and content of his prose work re-surfaces later in the book, towards the end of the poet's war memories. In a short note entitled "Convulsiveness" Whitman briefly strays from his accounts of the Civil War to reflect on what he has written so far. Looking back at the previous pages, he fearfully concludes that these could prove "a batch of convulsively written reminiscences" (Whitman 1996: 799). However, the poet quickly dismisses this fear noting that such "convulsiveness" is in fact completely in line with the actual war experience and this justification again points to the link between the themes Whitman explores and the style of his composition. As in the case of the ferries and the seashore, the Civil War provides the images, but apparently accounts for certain organizational principles in Whitman's prose, as well.

Comments about the structure and organization of Specimen Days are further encountered in a piece introducing the "Nature-notes." Whitman here briefly describes some of his writing practices, stating that "the woods 
in mid-May and early June [are his] best places for composition" (Whitman 1996: 804). In the footnote below the text, he announces that he is entering upon new themes, abruptly but "without apology," observing that the essays on the Civil War were "temporary episodes, thank heaven!" (Whitman 1996: 804) From this point, Whitman will "restore [his] book to the bracing and buoyant equilibrium of concrete outdoor Nature, the only permanent reliance for sanity of book or human life" (Whitman 1996: 804). The sigh of relief expressed in this footnote suggests how difficult it was for Whitman to accept the reality of the Civil War and incorporate it in his prose and poetry. The poet went through a great struggle searching for a way to insert his war-poetry collection, Drum-Taps, into Leaves of Grass, and writing about the Civil War in prose was not an easier task.

Another problematic issue was finding the appropriate title for his collection of autobiographic essays. Whitman gives an insight into this search for title in "Cedar-Plums Like - Names" and in the footnote attached he provides "a list of suggested and rejected names for this volume, or parts of it" (Whitman 1996: 910) with some thirty titles. Finally, Whitman addresses the reader:

Then reader dear, in conclusion, as to the point of the name for the present collection, let us be satisfied to have a name - something to identify and bind it together, to concrete all its vegetable, mineral, personal memoranda, abrupt raids of criticism, crude gossip of philosophy, varied sands clumps. (Whitman 1996: 909)

Whitman admits that it is "a profound, vexatious, never-explicable matter - this of names" (Whitman 1996: 909). The "reader dear" will recall that similar issue haunted the poet through his several editions of Leaves, and that the 12 original poems obtained their present titles only later.

Approaching the end of his autobiography, Whitman sets forth his final autopoetic observations in the essay "Final Confessions - Literary Test." In conclusion to his "garrulous notes" the poet again expresses some insecurity with regard to what he has written: "There have doubtless occurr'd some repetitions, technical errors in the consecutiveness of dates, in the minutiae of botanical, astronomical, \&c., exactness, and perhaps elsewhere" (Whitman 1996: 948), and he attributes possible mistakes to the hot weather and hurry. Specimen Days has been widely used as a source of data on Whitman's life, even though the quoted statement clearly suggests potential unreliability of the author's narration. According to Whitman, the only thing he can vouch for is the "deepest veracity" of his subjective vision and the authenticity of the presented specimen-days of his life. He emphasizes the "bona fide spirit and relations, from author to reader" (Whitman 1996: 948), which should reassure his readers that, whatever the result, the author had the best of intentions.

In this penultimate essay, Whitman offers another insight into his composition principles, "confessing" that he had to change his original plan for "a Nature-poem," because the narrative mode here made him feel more "at ease." The supremacy of nature over art in poetry-writing is emphasized once again and the nature's role is extended to that of the ultimate literary critic. Whitman wonders whether "the last deciding tests applicable to a book are 
entirely outside of technical and grammatical ones," and finally concludes: "I have fancied the ocean and the daylight, the mountain and the forest, putting their spirit in a judgment on our books." (Whitman 1996: 949) ${ }^{12}$

\section{Conclusion - Where to look for Whitman}

Writing about writing in his Specimen Days, Whitman continues to act as a founding father of the American poetry by insisting on the liberation from foreign influences and on exploring the distinctly American themes. Traveling across the American continent, he never misses the chance to express exhilaration over the beauty of those vast regions and their inhabitants and urges poets to adopt these as subjects for their art. Whitman himself incorporated objects from his surroundings in his poetry, which he explicitly mentions in Specimen Days essays. By discussing his own writing principles he emphasizes the "invisible influence" of ferries, seashores and nature in general.

In more than one way Whitman's prose writings are complementary to his poetry and can serve as a key for interpreting it. The obvious thematic and stylistic parallels suggest a possibility and perhaps a necessity of comparative readings of his poems and essays. Specimen Days also offer a valuable insight into Whitman's writing practices and organizational principles and his occasional insecurities and misgivings provide a truly authentic view of the poet's mind at work. In "Song of Myself" Whitman advised us to look for him in the grass under our boot soles. When it comes to understanding him as a poet, his prose writings can also be useful.

\section{References}

[Anonymous] 1855: [Anonymous, A curious title]. Life Illustrated (28 July 1855): page number unknown. Available at: http://whitmanarchive.org/criticism/ reviews/leaves1855/anc.00175.html. Last accessed May 1, 2016.

Asselineau 1999: R. Asselineau, The Evolution of Walt Whitman: An Expanded Edition: The Creation of a Book. Iowa City: University of Iowa Press.

Balkun 1999: M. M. Balkun, Whitman's Specimen Days and the Culture of Authenticity, Iowa City: Walt Whitman Quarterly Review 17 (Summer 1999), pp. 15-24.

Dougherty 2006: J. Dougherty, Crossing Brooklyn Ferry, in D. Kummings (ed.), A Companion to Walt Whitman, Malden, MA: Blackwell Publishing Ltd, pp. 484-495.

Erkkila 1996: B. Erkkila, Whitman the Political Poet, New York: Oxford University Press.

Folsom 2005: E. Folsom, Whitman Making Books, Books Making Whitman. A Catalog \& Commentary, Iowa City: University of Iowa.

12 These final thoughts on the crucial link between nature and literature are given in brackets, almost as an offhand remark, which by no means suggests that this is something the poet mentions merely in passing. Bracketed observations and addresses to the reader are not rare in Whitman's prose and are usually concerned with important postulates of his art. 
Norton 1855: C. E. Norton, [Review of Leaves of Grass (1855)]. Putnam's Monthly: A Magazine of Literature, Science, and Arts 6 (September 1855), pp. 321-3. Available at: http://whitmanarchive.org/criticism/reviews/leaves1855/ anc.00011.html. Last accessed May 1, 2016.

Warren 2006: J. P. Warren, Style, in D. Kummings (ed.), A Companion to Walt Whitman. Malden, MA: Blackwell Publishing Ltd, pp. 377-391.

Whitman 1996: W. Whitman, Poetry and Prose. New York: The Library of America.

\section{Бојана Л. Аћамовић \\ ПОТРАЖИТЕ ГА ИСПОД СВОЈИХ ЂОНОВА... ИЛИ У ЊЕГОВОЈ ПРОЗИ}

Резиме

Рад анализира Витманову збирку аутобиографских есеја Specimen Days и релације које постоје између ових есеја и Витманове поезије. Поредећи прозу и поезију овог америчког песника, можемо запазити значајне сличности у погледу стила и тематике. Витманови есеји доносе препознатљиве стилске особености карактеристичне и за његову поезију, као што су понављање, паралелизми и каталози. Када су у питању теме, посебно је интересантно поредити Витманове прозне и поетске представе америчког грађанског рата, при чему се уочавају извесне разлике у фокусу и тону. Осим тога, есеји у збирци Specimen Days нуде драгоцене увиде у песникове поетичке принципе, јер Витман у њима разматра структуру и организацију саме књиге. На основу дате анализе закључујемо да Витманова проза, поред свог уметничког и биографског значаја, представља вредан додатни материјал за проучавање његове поезије.

Клучне речи: аутобиографија, метапоетика, америчка поезија, Волт Витман, Specimen Days 